\section{Oral Adenosquamous Carcinoma Mimicking a Pyogenic Granuloma: a Challenging Diagnos is}

Celina Faig Lima1, Renata Acay², Ana Lia Anbinder², Janete Dias Almeida², Yasmin Rodarte Carvalho ${ }^{2}$

\begin{abstract}
1University Braz Cubas, Mogi das Cruzes, São Paulo, Brazil. ${ }^{2}$ Department of Bioscience and Oral Diagnosis, São Paulo State University (UNESP), Institute of Science and Technology, São José dos Campos, SP, Brazil
\end{abstract}

Correspondence: Janete Dias Almeida, Av. José Longo, 777, Jd São Dimas, 12245-000, São José dos Campos, SP, Brasil. Tel: +55-12-3947-9010. e-mail: janete@fosjc.unesp.br

\begin{abstract}
Adenosquamous carcinoma is an aggressive variant of squamous cell carcinoma. This report describes a case of adenosquamous carcinoma with clinical features of a benign lesion and discusses the differential diagnoses, especially regarding histopathological and immunohistochemical analyses. A 45-year-old male was referred to our outpatient clinic complaining about a rapid-growing enlargement in hard palate. Clinical examination revealed an erythematous and pedunculated nodule with lobulated non-ulcerated surface. Excisional biopsy was performed following clinical diagnosis of pyogenic granuloma. Histologically, the specimen consisted of areas characterizing both welldifferentiated squamous cell carcinoma and true adenocarcinoma. After a broad list of immunohistochemical markers was evaluated (AE1/AE3, CEA, CK5, CK7, CK8/18, p53, p63 and Ki67), the diagnosis of adenosquamous carcinoma was rendered and the patient referred to complementary surgery. Adenosquamous carcinoma represents a challenge in diagnostic routine due to its rarity, diverse range of clinical presentations and histological features. Furthermore, classical clinical benign features may be present in malignant lesions; hence the submission of every surgical specimen to histological analysis is mandatory to provide the patient the adequate treatment.
\end{abstract}

Key Words: Adenosquamous carcinoma; Immunohistochemistry; Mouth mucosa; Squamous cell carcinoma

\section{Introduction}

Adenosquamous carcinoma of the head and neck is considered a rare variant of squamous cell carcinoma $(1,2)$. The variety of clinical features is reported, ranging from an indolent white lesion or a nodule (4) to an ulcerated, erosive erythroleukoplakia (5). Adenosquamous carcinoma presents strong male predilection, in a 6:1 ratio, and occurs in a wide age range (21-87 years) (1-6).

Histologically, according to the World Health Organization (1), adenosquamous carcinoma is comprised by two distinct components: squamous cell carcinoma (SCC) and true adenocarcinoma. The distinction between these components, however, is not always clear (1-7).

It is thought that adenocarcinoma presents a more aggressive clinical behavior than squamous cell carcinoma and a higher incidence of metastases (6). However some studies reported similar prognosis of adenosquamous carcinoma and squamous cell carcinoma in early stages (3), and no differences in overall survival among these entities (8).

The purpose of this article is to report a case of adenosquamous carcinoma with unusual clinical and histological features, which have led to difficulties in establishing a final diagnosis. A broad list of immunohistochemical markers is discussed in order to distinguish adenosquamous carcinoma from other differential diagnoses.

\section{Case Report}

A 45-year-old white male has been referred to our outpatient clinic with a chief complaint of a nodular lesion on hard palate noticed about one month before. The patient had an ill-fitting maxillary complete denture, which was circumventing the lesion. On clinical examination, there was a pedunculated erythematous nodule measuring $3 \times 5$-centimeter-wide, extending to soft palate, with welldefined borders and lobulated surface (Figs. 1A and 1B). With a clinical diagnostic hypothesis of pyogenic granuloma an excisional biopsy was performed (Fig. 1C).

On microscopic examination, the specimen presented either ulcerated areas or surface epithelium showing dysplasia and marked hyperplasia, from which apparently an epithelial neoplasia was arising (Fig. 2A). This neoplasia was characterized by proliferation of atypical keratinocytes, forming islands of neoplastic cells infiltrating the connective tissue in the lamina propria, consistent with well-differentiated squamous cell carcinoma (Fig. 2B). Often, in the center of these islands, keratin pearls were observed, occasionally with superposed dystrophic calcification. Also in their central portions, some islands presented acantholysis producing pseudoluminae that were empty or contained cellular debris. Individually, neoplastic cells showed moderate pleomorphism, mitotic figures, multiple evident nucleoli, and marked diskeratosis. Foreign 

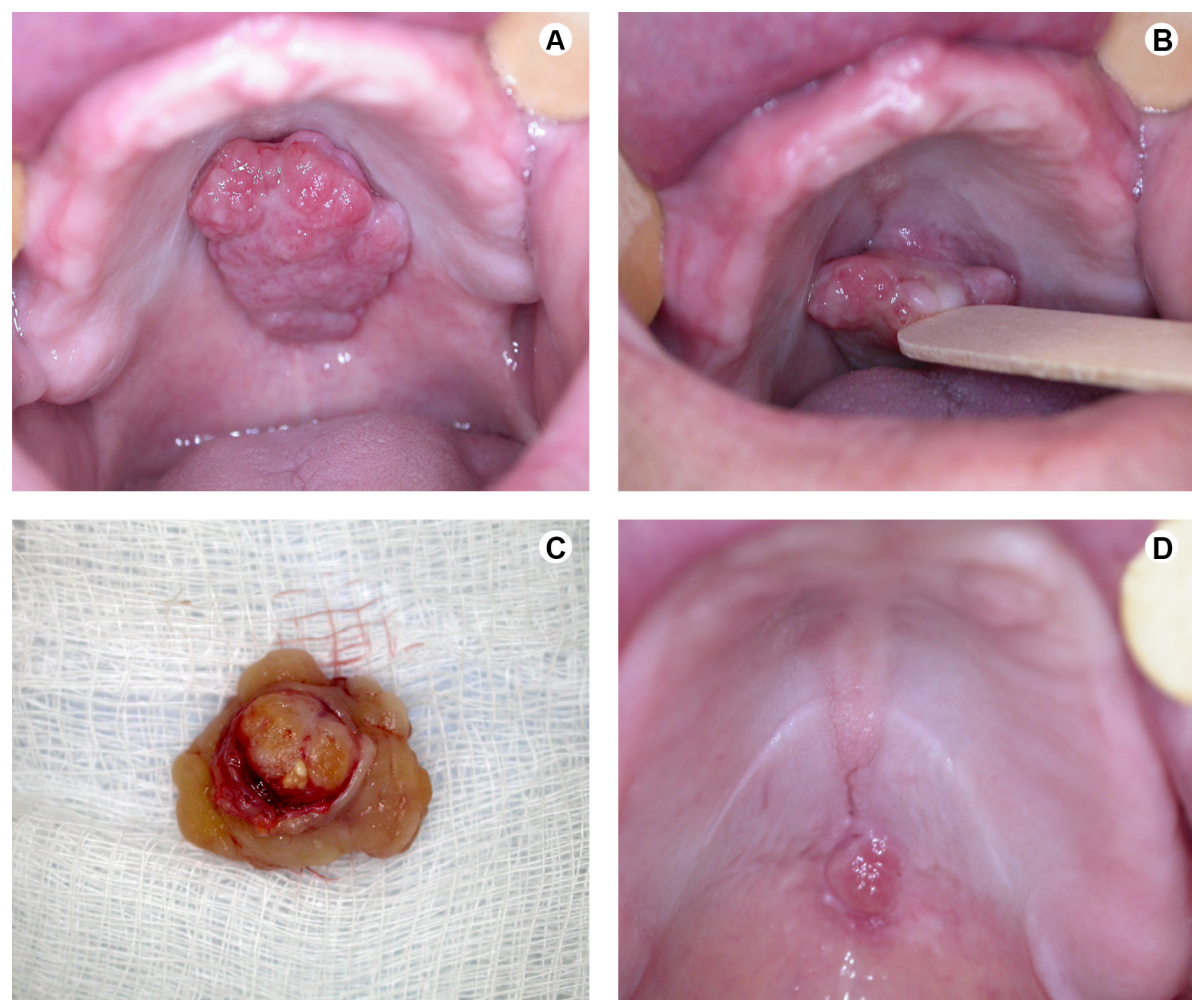

Figure 1. A: Clinical presentation of the nodule with lobulated surface. B: View of the pedunculated insertion of the lesion. C: Excisional biopsy fresh specimen, view from the insertion. D: Excisional biopsy site after 28 days, before complementary surgery.
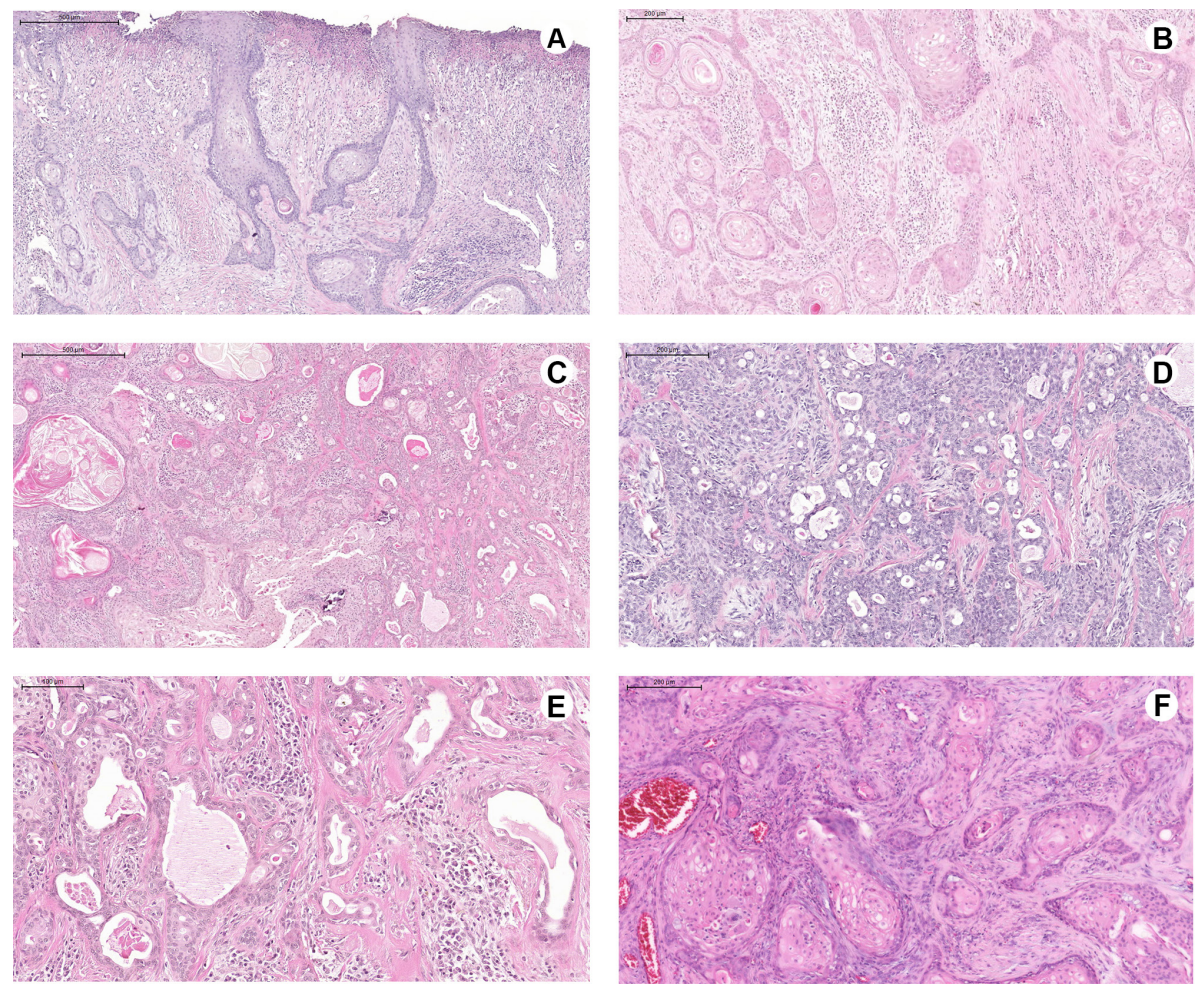

Figure 2. A: Squamous superficial component in contact with the surface epithelium, B: Squamous deep component showing keratin pearls. C: Transitional area between the squamous component and the adenocarcinomatous component. D: Adenocarcinomatous component. E: Adenocarcinomatous component showing duct-like structures, some exhibiting luminal content. F: Squamous cell carcinoma after surgical complementation. 
body reaction was also present, with giant cells surrounding keratin pearls and dystrophic calcification foci. In deeper portions of the lesion, a distinct glandular neoplasia could be observed (Fig. 2C), showing tubular structures limited by two or more layers of epithelial cells, frequently containing eosinophylic pale material (Fig. 2D). The stroma consisted of dense connective tissue with capillary blood vessels, showing diffuse mononuclear inflammatory infiltrate and, in some areas, myxoid features. The lesion margins were poorly defined, with highly infiltrative aspect in the deeper front of invasion. Peripheral portions of the specimen showed minor salivary glands apparently not affected by the tumor.

The histological hypotheses included squamous cell carcinoma, mucoepidermoid carcinoma, and even pleomorphic adenoma. Throughout the diagnostic process, the hypotheses of acantholytic squamous cell carcinoma and of adenosquamous carcinoma were also included.

Histochemical staining with PAS, PAS-diastase, and mucicarmine only evidenced the content of the pseudoluminal structures. Immunohistochemical analysis was then applied and the results are summarized in Table 1. Considering these results and the histological features, the diagnosis of adenosquamous carcinoma was rendered.

Four weeks after the post-operative appointment, a residual lesion or local recurrence of the lesion was noted (Fig. 1D).

Table 1. A summary of the immunohistochemical findings that concluded the final diagnosis of adenosquamous carcinoma. All immunohistochemistry reactions were done using humid heat for target retrieval and streptavidin-biotin-peroxidase system for detection. Positive and negative controls for every antibody were also included.

\begin{tabular}{|c|c|c|}
\hline Antibody & Clone & Result \\
\hline $\mathrm{AE} 1+\mathrm{AE} 3$ & AE1/AE3 & $\begin{array}{l}\text { Positive in all epithelial- } \\
\text { originated tissues }\end{array}$ \\
\hline CK5 & EP1601Y & Positive in squamous component \\
\hline CK8/18 & 5D3 & $\begin{array}{c}\text { Positive in adenocarcinomatous } \\
\text { component }\end{array}$ \\
\hline CK7 & $\begin{array}{l}\text { OV-TL } \\
12 / 3\end{array}$ & $\begin{array}{l}\text { Positive in adenocarcinomatous } \\
\text { component, scarce in squamous } \\
\text { component, negative in } \\
\text { surface epithelium }\end{array}$ \\
\hline CEA & Policlonal & $\begin{array}{c}\text { Positive in adenocarcinomatous } \\
\text { component }\end{array}$ \\
\hline Ki67 & SP6 & $\sim 10 \%$ proliferation index \\
\hline$\alpha \mathrm{SML}$ & $1 \mathrm{~A} 4$ & $\begin{array}{l}\text { Negative, only positive in } \\
\text { stromae capillary vessels }\end{array}$ \\
\hline p53 & D0-7 & $\begin{array}{l}\text { Specially on adenocarcinomatous } \\
\text { component, overall scarce }\end{array}$ \\
\hline p63 & $4 \mathrm{~A} 4$ & $\begin{array}{l}\text { Specially on adenocarcinomatous } \\
\text { component, overall scarce }\end{array}$ \\
\hline
\end{tabular}

CEA: Carcinoembrionic antigen; $\alpha$ SMA: Alpha smooth muscle actin.
Due to the final diagnosis of a malignant lesion with compromised surgical margins, the patient was submitted to complementary surgery in a cancer referral hospital. After surgical complementation, the histological exam of the specimen was performed and confirmed the presence of squamous cell carcinoma component. Chest radiography did not show any evidence of pulmonary involvement. The patient has been followed up for two years, with no clinical signs of recurrence.

\section{Discussion}

This case presented very diverse clinical and microscopic features, hence several diagnostic hypotheses were raised both at clinical and histological examination. Our first clinical hypothesis was pyogenic granuloma, considering the aspect of the maxillary complete denture and poor oral hygiene. Despite the low prevalence of pyogenic granuloma on the palate (4.2\% in Brazilian population) (9), a palatal pyogenic granuloma with clinical aspects similar to our case has already been reported (10). Caldeira et al. (11) also considered pyogenic granuloma among the possible clinical diagnoses for an erythematous, lobulated, pedunculated lesion located in hard palate. In their case, however, there were no local etiologic factors associated to the lesion and this hypothesis was excluded. Their final diagnosis was benign fibrous histiocytoma rich in granular cells.

Some pedunculated lesions were not included in clinical diagnostic hypothesis, as fibroma and hyperplasia (12), because of the fast-growing enlargement of the nodule. Neural tumors also occur on the palate, and only in rare occasions can be pedunculated, as solitary neurofibroma (13). Moreover, the pedunculated morphology was decisive to rule out all salivary gland tumors from the list of differential clinical diagnoses.

To the best of our knowledge, there are no other cases of adenosquamous carcinoma in oral cavity with clinical findings similar to the presented case: hard palate location and pedunculated aspect of the lesion. The last is a strong benign feature of soft tissue tumors that associated with inflammatory conditions mentioned above suggested the initial hypothesis of pyogenic granuloma.

The incidence of minor salivary gland tumors, both benign and malignant, in hard palate is high. Even though in our case the evidence of malignancy has not been found clinically, the hypothesis of mucoepidermoid carcinoma could be raised, since this entity occurs frequently in hard palate and in a wide range of ages (14). Mucoepidermoid carcinoma may present several clinical appearances other than the classical submucosal bluish growth with fixed borders and may mimic benign lesions (11). The benign salivary gland tumor with highest incidence in hard palate is certainly pleomorphic adenoma, which affects young 
to middle-aged adults, presenting as a painless, slowly enlarging mass. Pleomorphic adenomas are usually located laterally in posterior hard palate and the mass usually presents regular surface (15). In the present case, the mass was lobulated and located centrally in hard palate.

Due to the benign characteristics of the lesion and clinical history, malignant tumours were not considered as hypotheses, although some oral manifestations of malignant diseases, such as non-Hodgkin's lymphomas may occur in the palate, with unusual reports of subtype B (16-17) even as nodular lesion (17).

On histopathological evaluation, the first thought was that the lesion would be a well-differentiated squamous cell carcinoma, since almost all features under light microscope were consistent with that. This diagnosis was not rendered due to a rather small, deeper part of the specimen showing adenoid neoplastic components that were definitely not part of the surrounding normal minor salivary glands. Mokhtari et al. (18) reported a similar situation, in which the initial histopathological diagnosis was squamous cell carcinoma and the adenocarcinomatous component was only noticed in metastatic cervical lymph nodes. In the same report, the authors confirm that, revisiting the slides of the primary tumor, it was possible to identify very discrete neoplastic gland-like structures using specific histochemical tests and the diagnosis was then changed to adenosquamous carcinoma. Likewise, Fonseca et al. (3) described a lesion initially diagnosed as epithelial dysplasia with focal microinvasive well-differentiated squamous cell carcinoma. In a local recurrence after 12 months of follow-up, with different clinical appearance from the beginning, the lesion presented features consistent with adenosquamous carcinoma (3).

Commonly, mucoepidermoid carcinoma is claimed to be the main histological differential diagnosis in this context. Gland-like structures and squamous cells tend to be intermingled in mucoepidermoid carcinoma while in adenosquamous carcinoma these two components are often in separate, distinct areas of the tumor (7). Also, the presence of a distinct adenocarcinomatous component only in deeper parts of the tumor and the massive presence of keratin pearls exclude the diagnosis of mucoepidermoid carcinoma (1).

Pleomorphic adenoma was also considered as a histological differential diagnosis, due to areas presenting tubular structures limited by two or more layers of cells, often presenting a mucinous content. However, this hypothesis was discharged with the observation of clear and exuberant cellular pleomorphism, mainly seen in the squamous component of the analyzed specimen.

The diagnosis of squamous cell carcinoma seemed to be appropriate for the case, except for two minor features observed under light microscope, which justified further studies: acantholysis in a small number of neoplastic squamous islands forming pseudoluminae, containing or not cellular debris, and the adenocarcinomatous component, that clearly was not part of the normal minor salivary glands of the hard palate. Hence, two other histological hypotheses were then considered: acantholytic squamous cell carcinoma and adenosquamous carcinoma, respectively.

Acantholytic squamous cell carcinoma is another rare variant of squamous cell carcinoma, characterized by acantholysis of neoplastic squamous cells, creating pseudoluminae and a false appearance of glandular differentiation (1). As mentioned before, the present case showed some areas with these pseudoluminae. However, these spaces were filled with a pale component that stained positively to PAS, both with and without diastase enzymatic digestion, and to mucicarmine, suggesting real glandular differentiation in most of these epithelial islands. Besides, in immunohistochemical analysis, the present case was immunopositive for carcinoembrionic antigen, excluding acantholytic squamous cell carcinoma and reinforcing the final diagnosis of adenosquamous carcinoma (1).

Immunohistochemical findings were essential to reach the final diagnosis of adenosquamous carcinoma in the present case. AE1/AE3 stained positive in all neoplastic cells and in the surface epithelium, indicating the epithelial origin of the lesion (Fig. 3A). However when analyzing different molecular weight keratins separately, it became evident the dual histomorphogenesis of the neoplastic cells. That was confirmed by the positive staining for CK5 (high weight) in the squamous component (Fig. 3B) and the positive staining for CK8/18 (low weight) in the adenocarcinomatous component (Fig. 3C). Staining to CK7 (low weight) was strongly positive in the adenocarcinomatous component and, interestingly, it was more intense in cells in proximity with the luminae and it became progressively less intense, yet positive, in peripheral cells of adenocarcinomatous islands (Fig. 3D). The surface epithelium was negative to CK7. Fonseca et al. (3) observed CK7 immunopositive cells in adenocarcinomatous structures and in transitional epithelial structures, and not in surface epithelium. These authors also observed positivity to CK8 and CK18 in the adenocarcinomatous component of adenosquamous carcinoma.

Carcinoembrionic antigen is a marker largely used for the final diagnosis of adenosquamous carcinoma. The present case showed scarce positivity in the squamous component and intense positivity in the adenocarcinomatous component (Fig. 3E), contrasting with the case reported by Abdelsayed et al. (6) in which only the adenocarcinomatous component was strongly 
positive to this marker. Oppositely, Sheahan et al. (7) did not observe any positivity to carcinoembrionic antigen in their adenosquamous carcinoma case. Also controversial was the proliferation index based on Ki67 immunostaining: it was considered low (approximately 10\%) for a malignant lesion of known aggressive behavior (Fig. 3F).

The p63 gene encodes a group of proteins that are expressed in basal and parabasal layers in normal oral mucosa, in squamous cell carcinoma of the head and neck (19), in basal and myoepithelial cells of normal salivary gland tissue as well as basal/myoepithelial/squamoid elements in biphasic salivary gland tumors, in purely myoepithelial tumors, and in excretory duct type tumors
(20). Usually, in adenosquamous carcinoma, tumor cells in areas with squamous differentiation diffusely express p63 in their nuclei and rare tumor cells in areas with glandular differentiation express p63 (21). In our case, however, we found only scarce positivity to p63, mainly in adenocarcinomatous component, as well as low Ki67 labeling index, what contributes to its peculiarity.

In conclusion, adenosquamous carcinoma represents a challenge in diagnostic routine for its rarity, diverse range of clinical presentations and histological features, since the adenocarcinomatous component may be, at times, difficult to identify. The recognition of the specific subtype of squamous cell carcinoma is of great significance in
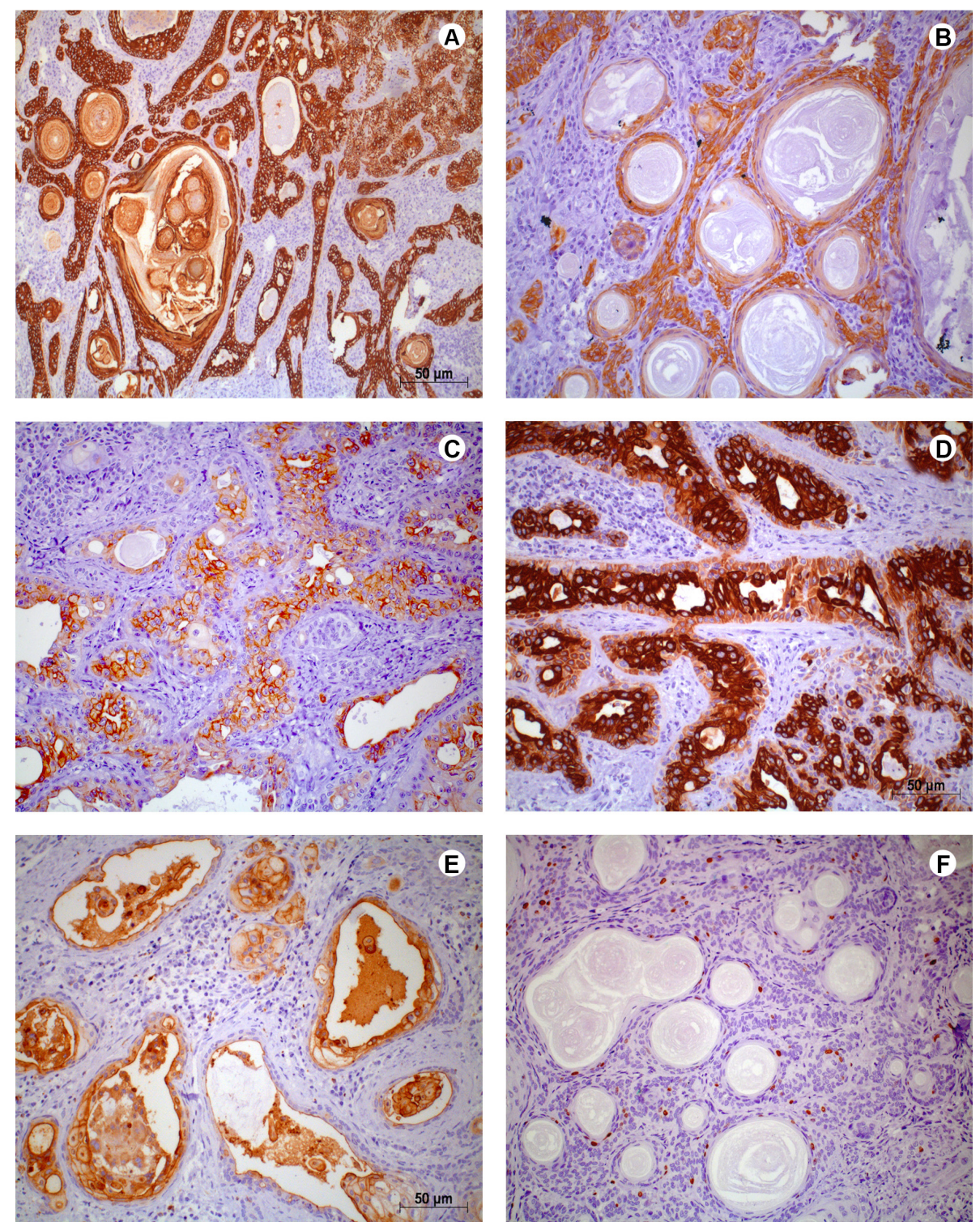

Figure 3. Immunohistochemical staining, original magnification 200x. A: AE1/AE3: Strong positivity in squamous and adenocarcinomatous components. B: CK5: Positive staining mainly seen in squamous component. C: CK8/18: Positive staining mainly seen in adenocarcinomatous component. D: CK7: Positive staining in adenocarcinomatous component. More intense staining was observed in luminal cells and less intense staining in peripheral areas of adenocarcinomatous islands. E: CEA: positive in adenocarcinomatous component and occasionally in squamous component. F: Ki67: proliferation index of approximately 10\% in both components of the lesion 
prognosis and outcome.

\section{Resumo}

0 carcinoma adenoescamoso é uma variante agressiva do carcinoma de células escamosas. Este relato descreve um caso de carcinoma adenoescamoso que apresenta características clínicas de uma lesão benigna e discute o diagnóstico diferencial, especialmente em relação à análise histopatológica e imuno-histoquímica. Um homem de 45 anos foi encaminhado ao nosso serviço queixando-se um aumento de volume de rápido crescimento no palato duro. 0 exame clínico revelou um nódulo eritematoso e pedunculado com superfície lobulada não ulcerada. Foi realizada biópsia excisional seguindo a hipótese clínica de granuloma piogênico. Histologicamente o fragmento consistia em áreas de carcinoma de células escamosas bem diferenciado e áreas de adenocarcinoma verdadeiro. Após a avaliação de uma ampla lista de marcadores imuno-histoquimicos (AE1/AE3, CEA, CK5, CK7, CK8/18, p53, p63 e Ki67), o diagnóstico de carcinoma adenoescamoso foi atribuído e o paciente foi encaminhado à cirurgia complementar. 0 carcinoma adenoescamoso representa um desafio na rotina de diagnóstico, devido à sua raridade, diversificada gama de apresentações clínicas e caracteristicas histológicas. Além disso, características clínicas benignas podem estar presentes em lesões malignas, por isto a submissão de todas as peças cirúrgicas à análise histológica é obrigatória para fornecer ao paciente o tratamento adequado.

\section{References}

1. Cardesa A, Zidar N, Alos L. Acantolytic squamous cell carcinoma/ Adenosquamous carcinoma. In: Barnes L, Eveson JW, Reichart P, Sidransky D (editors). Pathology and genetics of head and neck tumours, World Health Organization Classification of Tumours. Lyon (France):IARC Press, 2005;129-131.

2. Schick U, Pusztaszeri M, Betz M, Ghadjar P, Demiroz C, Kaanders JH, et al. Adenosquamous carcinoma of the head and neck: report of 20 cases and review of the literature. Oral Surg Oral Med Oral Pathol Oral Radiol 2013,116:313-320.

3. Fonseca FP, Ramos LM, Vargas PA, de Almeida OP, Lopes MA, SantosSilva AR. Oral adenosquamous carcinoma: evidence that it arises from the surface mucosal epithelium. Histopathology 2012,61:321-323.

4. Masand RP, El-Mofty SK, Ma XJ, Luo Y, Flanagan JJ, Lewis JS. Adenosquamous carcinoma of the head and neck: relationship to human papillomavirus and review of the literature. Head Neck Pathol 2011, 5(2):108-116.

5. Mancusi G, Susani M, Kornfehl J, Girsch W, Kautzky M: Adenosquamous carcinoma of the palate. Laryngorhinootologie 2002,81:568-572.

6. Abdelsayed RA, Sangueza OP, Newhouse RF, Singh BS: Adenosquamous carcinoma: a case report with immunohistochemical evaluation. Oral Surg Oral Med Oral Pathol Oral Radiol Endod 1998,85:173-177.

7. Sheahan P, Fitzgibbon J, Lee G, O'Leary G: Adenosquamous carcinoma of the tongue in a 22-year-old female: report of a case with immunohistochemistry. Eur Arch Otorhinolaryngol 2003,260:509-512.

8. Kass Jl, Lee SC, Abberbock S, Seethala RR, Duvvuri U. Adenosquamous carcinoma of the head and neck: Molecular analysis using CRTC-MAML FISH and survival comparison with paired conventional squamous cell carcinoma. Laryngoscope 2015,125:E371-E376.

9. Gordón-Núñez MA, Vasconcelos Carvalho M, Benevenuto TG, Lopes MF, Silva LM et al.. Oral pyogenic granuloma: a retrospective analysis of 293 cases in a Brazilian population. J Oral Maxillofac Surg 2010,68:21852188.

10. Mahabob N, Kumar S, Raja S. Palatal pyogenic granuloma. J Pharm Bioallied Sci 2013,5:S179-S181.

11. Caldeira PC, Ribeiro DC, de Almeida OP, Mesquita RA, do Carmo MA: Tumor of the hard palate. Oral Surg Oral Med Oral Pathol Oral Radiol 2012,113:722-727.

12. Vidyanath $S$, Shameena PM, Johns DA, Shivashankar VY, Sudha S, Varma S. Reactive hyperplasic lesions of the oral cavity: A survey of 295 cases at a Tertiary Health Institution in Kerala. J Oral Maxillofac Pathol 2015;19:330-334.

13. Kodiya AM, Ngamdu YB, Sandabe MB, Isa A, Garandawa HI. Solitary isolated neurofibroma of the soft palate. J Surg Case Rep 2013;15:2013.

14. Wyszyńska-Pawelec G, Gontarz M, Zapała J, Szuta M: Minor salivary gland tumours of upper aerodigestive tract: a clinicopathological study. Gastroenterol Res Pract 2012:780453.

15. Rahnama M, Orzędała-Koszel U, Czupkałło L, Lobacz M: Pleomorphic adenoma of the palate: a case report and review of the literature. Contemp Oncol 2013,17:103-106.

16. Souto GR, Pereira TS, Castro AF, Mesquita RA. Diffuse large B-cell lymphoma, not otherwise specified of the palate: A case report. J Clin Exp Dent 2013,5:e287-e290.

17. Sahoo SR, Misra SR, Mishra L, Mishra S. Primary diffuse large B-cell lymphoma in the anterior hard palate: $A$ rare case report with review of literature. J Oral Maxillofac Pathol 2014,18:102-106.

18. Mokhtari S, Mohsenifar Z, Mokhtari S: Diagnostic histological features of metastatic lymph nodes in adenosquamous carcinoma. Pathol Res Pract. 2012,208:360-362.

19. Nylander K, Vojtesek B, Nenutil R, Lindgren B, Roos G, Zhanxiang W et al. Differential expression of p63 isoforms in normal tissues and neoplastic cells. J Pathol 2002;198:417-427.

20. Owosho AA, Aguilar CE, Seethala RR. Comparison of $p 63$ and $p 40$ $(\triangle N p 63)$ as basal, squamoid, and myoepithelial markers in salivary gland tumors. Appl Immunohistochem Mol Morphol 2016;24:501-508

21. Schick U, Pusztaszeri M, Betz M, Ghadjar P, Demiroz C, Kaanders JH et al. Adenosquamous carcinoma of the head and neck: report of 20 cases and review of the literature. Oral Surg Oral Med Oral Pathol Oral Radiol 2013;116:313-320. 